\title{
Did "Screeners" Increase Pediatric Tuberculosis Case Notification in Sindh, Pakistan?
}

\author{
Afshan Khurshid1*, Sven Gudmund Hinderaker ${ }^{2}$, Einar Heldal ${ }^{3}$, Razia Fatima4, Mahboobul Haq ${ }^{4}$, \\ Aashifa Yaqoob4 , Amanullah Ansari' ${ }^{1}$, Kashif Anwar, Ejaz Qadeer6, Ajay M. V. Kumar,8 \\ ${ }^{1}$ Provincial TB Control Program, Sindh, Pakistan \\ ${ }^{2}$ University of Bergen, Bergen, Norway \\ ${ }^{3}$ Norwegian Institute of Public Health, Oslo, Norway \\ ${ }^{4}$ National TB Control Program, Islamabad, Pakistan \\ ${ }^{5}$ National TB Control Program, Research, Islamabad, Pakistan \\ ${ }^{6}$ Pakistan Institute of Medical Sciences, Islamabad, Pakistan \\ ${ }^{7}$ International Union against Tuberculosis and Lung Disease, Paris, France \\ ${ }^{8}$ International Union against Tuberculosis and Lung Disease, South-East Asia Office, New Delhi, India \\ Email: *afshankhurshid@hotmail.com
}

How to cite this paper: Khurshid, A., Hinderaker, S.G., Heldal, E., Fatima, R., Haq, M., Yaqoob, A., Ansari, A., Anwar, K., Qadeer, E. and Kumar, A.M.V. (2017) Did "Screeners" Increase Pediatric Tuberculosis Case Notification in Sindh, Pakistan? Journal of Tuberculosis Research, 5, 81-86. https://doi.org/10.4236/jtr.2017.51009

Received: January 20, 2017

Accepted: March 26, 2017

Published: March 29, 2017

Copyright ( 2017 by authors and Scientific Research Publishing Inc. This work is licensed under the Creative Commons Attribution International License (CC BY 4.0).

http://creativecommons.org/licenses/by/4.0/

\begin{abstract}
To identify missing childhood Tuberculosis (TB) cases, "screeners" (hospitalbased health workers trained to screen accompanying contacts of TB patients for symptoms) were introduced in eight tertiary care hospitals of Sindh, $\mathrm{Pa}$ kistan in 2013. There was a 55\% increase in childhood TB notifications in 2014 compared to 2012 in facilities with screeners $(n=8)$ compared to $40 \%$ increase in facilities without screeners $(\mathrm{n}=22)$. This apparent association disappeared when stratified by presence of "trained pediatrician" whose introduction was associated with a massive increase in notifications while transfer was associated with a marked decrease. In conclusion, screeners were not associated with increase in pediatric TB case notifications.
\end{abstract}

\section{Keywords}

Childhood Tuberculosis, Pediatricians, Screener, Xpert MTB/RIF, SORT IT

\section{Situation and Setting}

Childhood Tuberculosis (TB) has received low priority globally for many years [1]. Pakistan has an estimated TB incidence of 270 per 100,000 population and ten percent of the estimated TB cases in 2015 were children [2]. Screening of household contacts of infectious index cases has been recommended for decades 
but implementation has been limited [1] [3]. Most childhood TB cases are therefore either missed or detected late and passively among those seeking care at health facilities [4] [5]. To address this, several initiatives have been planned and implemented in Pakistan in the last five years-these include introduction of rapid diagnostics like Xpert MTB/RIF, expanding the scope of contact tracing to the immediate community beyond the household, engaging the private health sector through public-private mix initiatives, ensuring availability of a trained pediatrician in secondary and tertiary care facilities which account for most of pediatric $\mathrm{TB}$ case detection and so on.

One such intervention was introduction of "screeners" (trained health care workers deployed in selected secondary and tertiary care hospitals and dedicated to screen the accompanying contacts of diagnosed TB patients) in 2013, by the National TB Control Program of Pakistan and the Provincial TB Control Program (PTP) in Sindh province. In this paper, we aim to assess if introduction of "screeners" was associated with a change in childhood TB case notification in Sindh province, Pakistan.

Sindh province has 29 districts and a population of over 42 million [6]. The PTP is responsible for the TB control activities. There are 282 functional public and private basic management units for tuberculosis across the province. In each district, TB care is provided through a network of rural health centers, basic health units, and community-based lady health workers. There are 36 tertiary and secondary health care hospitals providing childhood TB management services. The algorithm for diagnosis of childhood TB is primarily clinical assessment performed by a physician at the hospital using a scoring chart formulated by Pakistan Pediatric Association (PPA) [7], based on the presentation of TB signs and symptoms, and test results of sputum or other specimens. The Xpert MTB/RIF ${ }^{\circledast}$ test was introduced in 2011 and is currently available at 20 sites across Sindh.

\section{Aspect of Interest}

In 2013 screeners were introduced at eight public tertiary and secondary care hospitals. The screeners were health workers (minimum qualification: graduation) selected from the community with 1 - 2 years of experience in Public health [8]. The screeners were trained on contact tracing and the revised programme guidelines [9] through frequent "on-spot trainings" and constant supervision and monitoring. The screeners were stationed close to chest departments and pediatric outpatient departments. They screened verbally the accompanying child contacts of TB patients for cough for 2 weeks or more, fever with night sweats and weight loss. The presumptive TB patients thus identified were referred to the physician for further examination.

We used an ecologic study design and compared the percent change in aggregate childhood TB cases notified before (2012) and after (2014) the intervention in facilities with screeners $(n=8)$ and those without screeners $(n=22)$. The study population included all pediatric TB cases notified at 30 selected health facilities in the years 2012 and 2014. The key exposure variables assessed were 
presence of screeners, presence of Xpert MTB/RIF and presence of trained pediatrician. The source of data was the quarterly summary reports of TB case notification and programme management reports, which were verified by reviewing the TB register at the facilities. These aggregated data were double entered, validated and analysed using EpiData (v3.1 for entry and v2.2.2.183 for analysis).

Overall, there was a 55\% increase in childhood TB notifications in facilities with screeners as compared to $40 \%$ increase in those without screeners, an apparent association (Table 1). There were variations in magnitude and direction of change, when disaggregated by sex, age and type of TB. Notably, there was a higher increase in the non-intervention sites in $0-4$ year age group and the clinically confirmed pulmonary TB cases.

To understand this variation, we performed a stratified analysis by two key confounder variables (availability of Xpert MTB/RIF and availability of trained pediatrician) that were implemented around the same time as the intervention in question (Table 2). In facilities when Xpert was introduced in 2014, there was a higher increase in intervention sites compared to non-intervention sites (76\% vs. $11 \%)$ although this was not consistent across other strata.

While introduction of a trained pediatrician was associated with a massive increase in notifications (154\% in intervention sites versus $176 \%$ in non-intervention sites), the transfer of trained pediatricians was associated with a marked decrease in notification ( $-48 \%$ versus $-61 \%$ ) (Table 2 ). Thus, the apparent association between "screeners" and increase in childhood TB case notifications disappeared completely when stratified by availability of trained pediatrician.

Table 1. Percentage change in childhood TB case notification after introduction of health care facility based screeners in selected health care facilities of Sindh province, Pakistan.

\begin{tabular}{|c|c|c|c|c|c|c|}
\hline \multirow{2}{*}{$\begin{array}{l}\text { Number of pediatric } \\
\text { TB cases notified }\end{array}$} & \multicolumn{3}{|c|}{$\begin{array}{c}\text { Intervention } \\
\text { hospitals }(n=8)\end{array}$} & \multicolumn{3}{|c|}{$\begin{array}{l}\text { Non-Intervention } \\
\text { hospitals }(\mathrm{n}=22)\end{array}$} \\
\hline & $2012^{*}$ & $2014^{* *}$ & $\begin{array}{l}\text { Percent } \\
\text { change }\end{array}$ & 2012 & 2014 & $\begin{array}{l}\text { Percent } \\
\text { change }\end{array}$ \\
\hline Total & 728 & 1128 & $55 \%$ & 1764 & 2465 & $40 \%$ \\
\hline \multicolumn{7}{|l|}{ Sex } \\
\hline Male & 327 & 487 & $49 \%$ & 832 & 1180 & $42 \%$ \\
\hline Female & 401 & 641 & $60 \%$ & 932 & 1285 & $38 \%$ \\
\hline \multicolumn{7}{|l|}{ Age } \\
\hline 0 - 4 years & 203 & 324 & $60 \%$ & 576 & 1234 & $114 \%$ \\
\hline $5-14$ years & 525 & 804 & $53 \%$ & 1188 & 1231 & $4 \%$ \\
\hline \multicolumn{7}{|l|}{ Type of TB } \\
\hline $\begin{array}{l}\text { Bacteriologically } \\
\text { confirmed PTB }\end{array}$ & 54 & 84 & $56 \%$ & 134 & 162 & $21 \%$ \\
\hline Clinically confirmed PTB & 451 & 567 & $26 \%$ & 1141 & 1836 & $61 \%$ \\
\hline ЕРТВ & 223 & 477 & $114 \%$ & 489 & 467 & $-4 \%$ \\
\hline \multicolumn{7}{|l|}{ History of treatment } \\
\hline New & 717 & 1116 & $56 \%$ & 1710 & 2422 & $42 \%$ \\
\hline Previously treated & 11 & 12 & $9 \%$ & 54 & 43 & $-20 \%$ \\
\hline
\end{tabular}

$\mathrm{TB}=$ Tuberculosis, PTB = Pulmonary Tuberculosis, EPTB = Extra-pulmonary Tuberculosis. ${ }^{\star}$ Non-intervention year, ${ }^{*}$ Intervention year. 
Table 2. Percentage change in childhood TB case notification after introduction of health care facility based screeners, by presence of Xpert MTB/RIF and trained pediatrician, in selected health care facilities of Sindh province, Pakistan.

\begin{tabular}{|c|c|c|c|c|c|c|c|c|}
\hline \multirow{2}{*}{$\begin{array}{c}\text { Total number of } \\
\text { pediatric TB } \\
\text { cases notified }\end{array}$} & \multirow{2}{*}{$\begin{array}{l}\text { Number } \\
\text { of } \\
\text { facilities }\end{array}$} & \multicolumn{3}{|c|}{$\begin{array}{l}\text { Intervention } \\
\text { hospitals }\end{array}$} & \multirow{2}{*}{$\begin{array}{l}\text { Number } \\
\text { of } \\
\text { facilities }\end{array}$} & \multicolumn{3}{|c|}{$\begin{array}{c}\text { Non-Intervention } \\
\text { hospitals }\end{array}$} \\
\hline & & 2012 & 2014 & $\begin{array}{l}\text { Percent } \\
\text { change }\end{array}$ & & 2012 & 2014 & $\begin{array}{l}\text { Percent } \\
\text { change }\end{array}$ \\
\hline Total & 8 & 728 & 1128 & $55 \%$ & 22 & 1764 & 2465 & $40 \%$ \\
\hline \multicolumn{9}{|l|}{ Xpert MTB/RIF } \\
\hline Introduced in 2014 & 5 & 429 & 754 & $76 \%$ & 2 & 187 & 208 & $11 \%$ \\
\hline Present in 2012 and 2014 & 1 & 251 & 292 & $16 \%$ & 1 & 190 & 225 & $18 \%$ \\
\hline Absent in 2012 and 2014 & 2 & 48 & 82 & $71 \%$ & 19 & 1387 & 2032 & $47 \%$ \\
\hline \multicolumn{9}{|l|}{$\begin{array}{l}\text { Trained pediatrician } \\
\text { availability }\end{array}$} \\
\hline Present in 2012 and 2014 & 2 & 337 & 400 & $19 \%$ & 5 & 738 & 932 & $26 \%$ \\
\hline Absent in 2012 and 2014 & 0 & 0 & 0 & $0 \%$ & 6 & 139 & 130 & $-6 \%$ \\
\hline Trained in $2013-14$ & 5 & 259 & 659 & $154 \%$ & 10 & 446 & 1231 & $176 \%$ \\
\hline Withdrawn in 2014 & 1 & 132 & 69 & $-48 \%$ & 1 & 441 & 172 & $-61 \%$ \\
\hline
\end{tabular}

\section{Discussion}

Our study did not find any association between screeners and increase in childhood TB case notification in Sindh province of Pakistan. The apparent association seen in crude analysis completely disappeared on stratified analysis and could be explained by the presence of a trained pediatrician working with the program [10], rather than by the screeners. Introduction of a trained pediatrician was associated with a massive increase in childhood TB notifications, even in sites without screeners, while transfer was associated with a massive decline (akin to cessation of exposure leading to decline in outcome, one of the criteria to assess causality).

Strength of this study was that we used programmatic data and thus reflects the ground reality. This might be a limitation too, as comparability of the sites with and without screeners could not be ensured. Furthermore, analysis was done on aggregate data using an ecological design and hence should be interpreted with caution. Future research should focus on assessing costs, provider and patient perceptions of feasibility and acceptability of screeners.

\section{Conclusion}

"Screeners" were not independently associated with an increase in childhood TB case notification. This needs to be taken into consideration by the NTP before making decisions on national scale-up of screeners. Availability of trained paediatrician must be ensured for better results. 


\section{Acknowledgements}

This research was conducted through the Structured Operational Research and Training Initiative (SORT IT), a global partnership led by the Special Programme for Research and Training in Tropical Diseases at the World Health Organization (WHO/TDR). The training model is based on a course developed jointly by the International Union against Tuberculosis and Lung Disease (The Union) and Medécins sans Frontières (MSF/Doctors Without Borders). The specific SORT IT program which resulted in this publication was implemented by National Tuberculosis Programme Pakistan, through support of The Global Fund and WHO TDR, University of Bergen, The Union, Paris France, The Union South-East Asia Office, New Delhi, India . The authors thank Data Management officer, Mr. Kashif Khan who helped in data compilation.

\section{Funding}

The program is funded by the World Health Organization and the Global Fund for AIDS, Tuberculosis and Malaria in Pakistan. The publication fees are covered by the WHO/TDR.

\section{Author Contributions}

The Principal Investigator implemented, analysed and wrote the first and subsequent drafts of the paper. All other authors contributed to the writing of the first and subsequent drafts. All authors read and approved the final paper.

\section{References}

[1] Nelson, L.J. and Wells, C.D. (2004) Global Epidemiology of Childhood Tuberculosis. International Journal of Tuberculosis and Lung Disease, 8, 636-647.

[2] World Health Organization (2016) Global Tuberculosis Report. WHO, Geneva, Switzerland.

[3] World Health Organization (2014) Guidelines on the Management of Latent Tuberculosis Infection. WHO, Geneva, Switzerland.

[4] Yuen, C.M., Amanullah, F., Dharmadhikari, A., Nardell, E.A., Seddon, J.A., Vasilyeva, I., et al. (2015) Turning off the Tap: Stopping Tuberculosis Transmission through Active Case-Finding and Prompt Effective Treatment. The Lancet, 386, 2334-2343.

[5] Toman, K. (1979) Tuberculosis Case-Finding and Chemotherapy Questions and Answers. World Health Organization, Geneva, Switzerland.

[6] Government of Pakistan (2010) Population Welfare Department Sind. Sindh, Pakistan.

[7] National TB Control Programme, Federal Ministry of Health, Government of Pakistan (2006) National Guidelines for Diagnosis and Management of Tuberculosis in Children NTP Pakistan. http://www.ntp.gov.pk

[8] Amanullah, F. and Malik, A.A. (2015) Unmasking Childhood Tuberculosis in Pakistan: Efforts to Improve Detection and Management. International Journal of Tuberculosis and Lung Disease, 19, 47-49. https://doi.org/10.5588/ijtld.15.0443

[9] World Health Organization Stop TB Partnership Childhood TB Subgroup (2007) 
Chapter 4: Childhood Contact Screening and Management. International Journal of Tuberculosis and Lung Disease, 11, 12-15.

[10] Dendup, T., Dorji, T., Edgnton, M.E., Kumar, A.M.V., Wangchuk, D., Dophu, U., et al. (2013) Childhood Tuberculosis in Bhutan: Profile and Treatment Outcomes. Public Heal Action. The International Union against Tuberculosis and Lung Disease, 3, 11-14.

\section{Scientific Research Publishing}

Submit or recommend next manuscript to SCIRP and we will provide best service for you:

Accepting pre-submission inquiries through Email, Facebook, LinkedIn, Twitter, etc. A wide selection of journals (inclusive of 9 subjects, more than 200 journals)

Providing 24-hour high-quality service

User-friendly online submission system

Fair and swift peer-review system

Efficient typesetting and proofreading procedure

Display of the result of downloads and visits, as well as the number of cited articles Maximum dissemination of your research work

Submit your manuscript at: http://papersubmission.scirp.org/

Or contact jtr@scirp.org 